\title{
The bimodal rift-related Juscelândia volcanosedimentary sequence in central Brazil: Mesoproterozoic extension and Neoproterozoic metamorphism
}

\author{
Renato Moraes $^{\mathrm{a}, *}$, Reinhardt A. Fuck ${ }^{\text {b }}$, Márcio Martins Pimentel ${ }^{\text {b }}$, \\ Simone M.C.L. Gioia ${ }^{a}$, Maria H.B.M. de Hollanda ${ }^{a}$, Richard Armstrong ${ }^{c}$ \\ a Instituto de Geociências, Universidade de São Paulo, Rua do Lago, 562-Cidade Universitária, 05508-080 São Paulo, SP, Brazil \\ ${ }^{\mathrm{b}}$ Instituto de Geociências, Universidade de Brasília, 70910-900 Brasília, DF, Brazil \\ ${ }^{\mathrm{c}}$ Research School of Earth Sciences, National Australian University, Canberra, ACT 0200, Australia
}

Received 1 May 2004; accepted 1 July 2005

\begin{abstract}
The Barro Alto Complex and Juscelândia volcanosedimentary sequence are exposed in the central part of the Neoproterozoic Brasília belt of central Brazil. The former is a large (approximately $150 \mathrm{~km}$ long), boomerang-shaped, mafic-ultramafic, layered complex formed by two different intrusions metamorphosed under granulite facies. These rocks are tectonically overlain by rocks of the Juscelândia volcanosedimentary sequence, represented mainly by biotite-gneiss and amphibolite, or amphibolite facies metamorphic equivalents of rhyolite and basalt, respectively. New SIMS U-Pb zircon data and Sm-Nd isochron data presented herein help clarify the igneous and metamorphic evolution of the Juscelândia volcanosedimentary sequence, as well as its relationship with the Barro Alto Complex. Zircon grains from two biotite gneisses were analyzed by SIMS (SHRIMP) and indicate Mesoproterozoic dates, approximately $1.28 \mathrm{Ga}$, interpreted as the time of bimodal volcanism in a tectonic setting transitional between a continental rift and an ocean basin. Metamorphism is constrained by Sm-Nd garnet-whole-rock isochrons for garnet amphibolite and pelitic schists of the Juscelândia sequence, as well as for clinopyroxene-garnet amphibolite and garnet granulite of the Barro Alto Complex, which give ages between 0.74 and $0.76 \mathrm{Ga}$, in agreement with SIMS dates for metamorphic zircon rims. These new data are significant, because they establish that a single metamorphic event affected both the Barro Alto Complex and the Juscelândia sequence. Based on these new data, we present a modified tectonic model for the Brasília belt.
\end{abstract}

(C) 2006 Elsevier Ltd. All rights reserved.

Keywords: Barro Alto Complex; Juscelândia sequence; Mesoproterozoic; SHRIMP U-Pb; Brasília belt

\section{Introduction}

In Precambrian terrains, exposures of the lower and middle continental crust permit investigation of the processes that lead to the formation and subsequent modification of the continental crust. Several models propose that continental crust is formed in magmatic arcs due to the ascent and separation of andesitic magmas from the mantle wedge or oceanic slab above subduction zones; later accretion of these arcs by collision forms larger continental masses. At the same time, the lower crust is affected by deformation, high-grade metamorphism, and melting. However, in regions where the continental crust is extended, it is possible to promote crustal growth through

\footnotetext{
* Corresponding author. Fax: +55 1130914258.

E-mail address: moraes@igc.usp.br (R. Moraes).
}

the addition and underplating of mantle-derived magmas (Rudnick, 1990), which is normally accompanied by metamorphism and melting of the lower continental crust (Sandiford and Powell, 1986). We present a study of a segment of the lower to middle continental crust in central Brazil, represented by a Mesoproterozoic rift-related bimodal sequence. These rocks were subsequently involved in collisional processes and affected by deformation and highgrade metamorphism during the Neoproterozoic.

In central Brazil, the Brasília belt is a Neoproterozoic collisional orogen formed between the Amazon and São Francisco cratons during the Brasiliano Orogeny (Fuck et al., 1994; Pimentel et al., 2000). The belt extends for approximately $1100 \mathrm{~km}$, from western Minas Gerais through Distrito Federal and Goiás to the south of Tocantins (Fig. 1a,b). The Goiás Massif is exposed in the central part of the Brasília belt, composed of older rocks, including three large Proterozoic mafic-ultramafic layered bodies and associated volcanosedimentary sequences (Fig. 1b). One of the most intriguing 


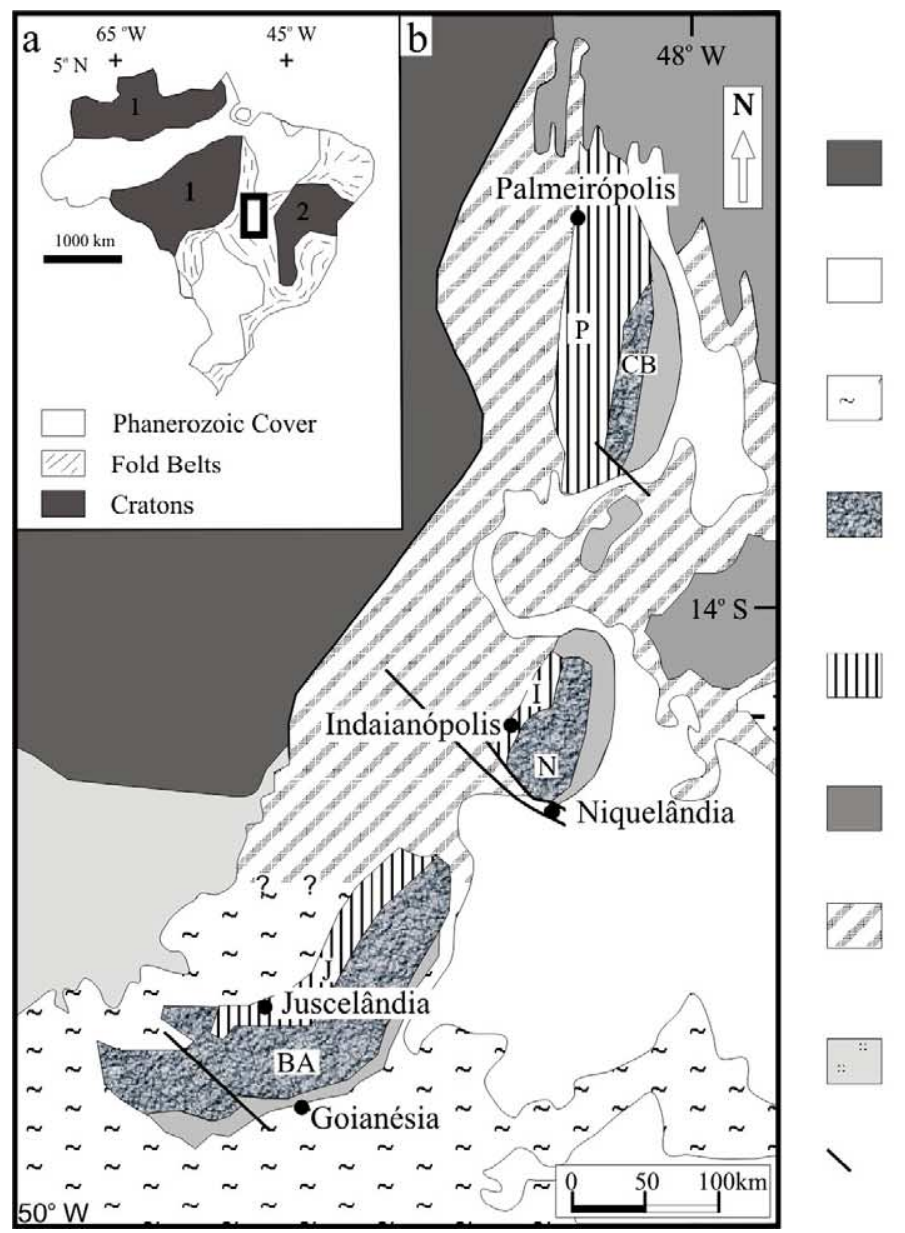

\section{Legend}

Goiás Magmatic Arc

Paranoá Group

Araxá Group

Mafic-ultramafic layered intrusions (BA -

Barro Alto Complex; N - Niquelândia

Complex; CB - Cana Brava Complex)

Volcano-sedimentary sequences (J Juscelândia Sequence; I - Indaianópolis Sequence; P - Palmeirópolis Sequence)

\section{Paleoproterozoic granite-gneisses} and volcano sedimentary sequences

\section{Serra da Mesa and Araí Groups}

\section{Archean Greenstone Belt and Granite- gneiss terranes}

faults

Fig. 1. (A) Main tectonic units of Brazil. 1, Amazon Craton; 2, São Francisco Craton. (b) Northern segment of Brasilia fold belt. Modified from Fuck et al. (1994).

and debated aspects of the geological evolution of the Goiás Massif is the tectonic significance of the mafic-ultramafic layered bodies and the adjacent volcanosedimentary sequences exposed along their western margins. We present new field data and $\mathrm{Sm}-\mathrm{Nd}$ and $\mathrm{U}-\mathrm{Pb}$ isotopic results from the Barro Alto Complex and Juscelândia sequence that clarify the age of volcanism of Juscelândia rocks, as well as the time of metamorphism of the volcanosedimentary rocks and adjacent layered bodies.

\section{Regional geological setting}

The Brasília belt borders the western and southern margins of the São Francisco Craton, comprising a foreland fold-andthrust belt, including a passive margin sedimentary sequence that underwent greenschist facies metamorphism (Fuck et al., 1994; Pimentel et al., 2000, 2004). Farther to the west, the metamorphic core consists of two units (Fig. 1b): (1) the Araxá Group, which includes turbidite-like sediments, volcanic rocks, and an ophiolite mélange and which underwent Barrovian-type metamorphism from greenschist to amphibolite facies conditions and was intruded by various granite bodies; and (2) the Anápolis-Itauçu Complex, which forms a NW-SE elongate region $(260 \times 70 \mathrm{~km})$ and comprises a large variety of granulite facies rocks and many granite and layered mafic-ultramafic intrusions. To the northwest is the Goiás Massif, a poorly understood crustal fragment composed of Archean, Paleoproterozoic, and Mesoproterozoic rock units that were reworked during the Neoproterozoic. To the southwest and west of the Goiás Massif, a large Neoproterozoic (ca. 900-630 Ma) juvenile magmatic arc is exposed (Goiás magmatic arc), which is dominated by calc-alkaline volcanosedimentary sequences and coeval tonalites and granodiorites (for recent comprehensive reviews, see Pimentel et al., 2000; Junges et al., 2002). The metamorphic peak and deformation are dated at approximately 650-630 Ma (Pimentel et al., 1991, 1997; Fischel et al., 1998; Piuzana et al., 2003a,b).

The Barro Alto (Fuck et al., 1981; Girardi et al., 1981; Danni et al., 1984), Niquelândia (Rivalenti et al., 1982; Girardi et al., 1986; Ferreira Filho et al., 1995, 1998b), and Cana Brava (Correia, 1994; Lima, 1997) complexes are layered maficultramafic bodies and mark the eastern border of the Goiás Massif. They are tectonically covered, respectively, by the Juscelândia (Fuck et al., 1981; Moraes and Fuck, 1994, 1999), Indaianópolis (Danni and Leonardos, 1980; also known as Coitezeiro, Brod and Jost, 1991, 1994), and Palmeirópolis (Ribeiro Filho and Teixeira, 1980; Araújo and Nilson, 1988; Araújo et al., 1995, 1996) volcanosedimentary sequences (Fig. 1b). The original stratigraphy and internal organization of the volcanosedimentary sequences and layered complexes 


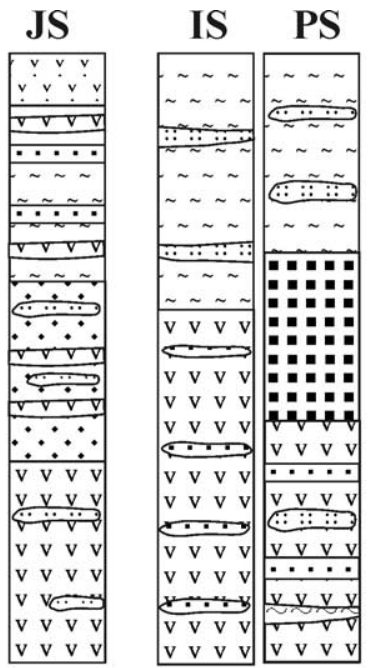

Volcano-sedimentary sequences

JS - Juscelândia sequence

IS - Indaianópolis sequence

PS - Palmeirópolis sequence

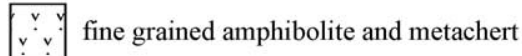

$\sim$ pelitic schists

$\because$ biotite gneisses and biotite-muscovite schist with feldspar

$\therefore \quad$ (acid metavolcanics and metasubvolcanics)

1-7 schists with feldspar and gneisses (acid to intermediate

E.:- metavolcanics)

$:::$ : metacherts and banded iron formation

$\begin{array}{lll}\mathrm{v} & \mathrm{v} \\ \mathrm{v} & \mathrm{v}\end{array}$ medium-grained amphibolite

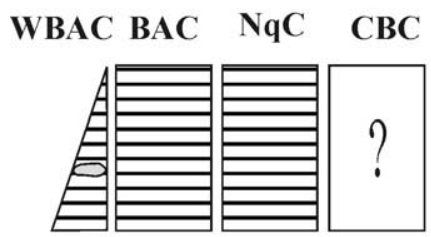

Mafic-ultramafic Layered Complexes

WBAC - western part of Barro Alto Complex

BAC - central and eastern parts of Barro Alto Complex

$\mathrm{NqC}$ - Niquelândia Complex

CBC- Cana Brava Complex

Upper Layered Series (Cafelândia Amphibolite and equivalent units)

\begin{tabular}{|c|c|c|c|}
\hline 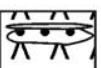 & $\Lambda-\Lambda-$ & ${ }^{115}$ & $-\Lambda-\Lambda$ \\
\hline & $\Lambda-\Lambda-\Lambda$ & $\Lambda-\Lambda-\Lambda$ & $\Lambda-\Lambda-$ \\
\hline & $-\Lambda-\Lambda-$ & $-\Lambda-\Lambda-$ & $-\Lambda-\Lambda$ \\
\hline & $\Lambda-\Lambda-\Lambda$ & $\Lambda-\Lambda-\Lambda$ & $\Lambda-\Lambda-$ \\
\hline & $-\Lambda-\Lambda-$ & $-\Lambda-\Lambda-$ & $-\Lambda-\Lambda$ \\
\hline 1 & & & \\
\hline & או & & \\
\hline & $\wedge \wedge$ & $\wedge \wedge$ & $\wedge \wedge$ \\
\hline$\pi \pi$ & $\wedge \wedge$ & $\wedge \wedge$ & $\wedge \wedge$ \\
\hline$\wedge \wedge$ & $\wedge \wedge$ & $\wedge \wedge$ & $\wedge \wedge$ \\
\hline$\wedge \wedge$ & $\wedge \wedge$ & $\wedge \wedge$ & $\wedge \wedge$ \\
\hline$\wedge \Lambda^{\circ}$ & $\wedge \wedge$ & $\wedge \wedge$ & $\wedge \wedge$ \\
\hline$\Leftrightarrow$ & $\wedge \wedge$ & $\wedge \wedge$ & $\wedge \wedge$ \\
\hline$\wedge \wedge$ & $\wedge \wedge$ & $\wedge \wedge$ & $\wedge \wedge$ \\
\hline$\Lambda$ & $\wedge \wedge$ & $\wedge \wedge$ & $\wedge \wedge$ \\
\hline
\end{tabular}

garnet amphibolite, meta-anorthosite, metagabbro, metatroctolite

felsic granulite (meta-granitoids)

Lower Layered Series

- $\quad$ sillimanite-garnet quartzite with fine grained mafic granulites

Upper Mafic Zone

metaquartz diorite

$\Lambda$ - $\downarrow$ meta-gabbronorite and meta-norite

Ultramafic Zone

meta-pyroxenites and serpentinites.

Lower Mafic Zone

$\wedge$ meta-gabbronorite and meta-norite

Fig. 2. Stratigraphic columns of the volcanosedimentary sequences and mafic layered complexes.

have been strongly disrupted by intense tectonism and concomitant metamorphism.

Nevertheless, several important similarities among the three sequences and layered complexes can be recognized (Fig. 2), which suggests they were originally part of a continuous geological unit (Ferreira Filho, 1998). The Niquelândia and Barro Alto layered complexes divide into two series, the upper layered series in the west and the lower layered series in the east (Ferreira Filho, 1998). Even though this stratigraphic division is not used by other authors, it is possible to recognize this classification in each unit to which they refer when discussing the local stratigraphy of each complex; therefore, we use these terms herein. This division is not observed in the Cana Brava Complex, where only the lower layered series has been recognized (Correia, 1994; Lima, 1997). In Niquelândia, the lower layered series is subdivided into the upper mafic, ultramafic, and lower mafic zones (Ferreira Filho et al., 1998a).
In Barro Alto, the lower mafic zone is significantly wider than in Niquelândia, the ultramafic zone is only exposed in the NNE segment, and the upper mafic zone is not present (Ferreira Filho, 1998). Both the ultramafic and upper mafic zones are absent in the EW segment of the complex, apparently due to tectonic omission (Moraes and Fuck, 2000). In the Barro Alto Complex, the main rock types in the mafic zones are norite and gabbronorite (Fuck et al., 1981), whereas the ultramafic zone is dominated by dunite and harzburgite, with minor orthopyroxenite, websterite, and gabbronorite (Fuck et al., 1981; Correia, 1994; Lima, 1997; Ferreira Filho, 1998). In the EW segment of the Barro Alto Complex, more evolved rock types-like biotite-bearing norite, diorite, and quartz diorite to tonaliteare abundant at the top of the lower layered series; similar rocks are recognized in Niquelândia as well (Ferreira Filho, 1998). Aluminous granulites bearing ultra-high-temperature mineral assemblages are metamorphic products of 
peraluminous granite bodies and enclosed by rocks of the lower and upper layered series (Moraes and Fuck, 2000). Along the contact between the lower and upper layered series, an approximately $20 \mathrm{~km}$ long belt of sillimanite-garnet quartzite and other metasedimentary rocks is exposed (Fuck et al., 1981; Moraes and Fuck, 1994, 1999, 2000). These rocks were affected by granulite facies metamorphism at ultra-high temperatures $\left(T>950^{\circ} \mathrm{C}\right)$ that transition to lower $P$ and $T$ conditions in the upper layered series (Ferreira Filho et al., 1998a; Moraes and Fuck, 2000).

The upper layered series, exposed in the Barro Alto and Niquelândia complexes, is dominated by heterogeneously deformed and metamorphosed gabbro and anorthosite, with minor troctolite and olivine gabbro (Fuck et al., 1981; Rivalenti et al., 1982; Danni et al., 1984; Girardi et al., 1986; Ferreira Filho et al., 1998b). A considerable portion of the Barro Alto Complex is dominated by the Cafelândia amphibolite, a coarse-grained, banded amphibolite with granulite facies assemblages (Moraes and Fuck, 1994, 2000).

Rocks of the lower mafic zone were thrust over Paleoproterozoic basement gneisses and granites by the Rio Maranhão thrust system (Fonseca and Dardenne, 1995; Fonseca, 1996), a NNE-trending low- to medium-angle shear zone, indicating tectonic transport to the east. Within this shear zone, rocks from the base of the lower mafic zone and underthrusted granite and gneiss were converted to mylonite with amphibolite to greenschist facies mineral assemblages. To the south and east of the Barro Alto Complex, orthogneiss and granite represent the basement of the Araxá and Paranoá groups in the Goianésia-Barro Alto area (Fuck et al., 1981).

The Juscelândia volcanosedimentary sequence comprises a bimodal volcanic association (now amphibolite and felsic gneiss) that also includes minor alkaline metavolcanic rocks and metasedimentary rocks dominated by pelitic schist, with minor metachert, calc-silicate rocks, and quartzite (Fuck et al., 1981; Danni et al., 1984; Moraes and Fuck, 1994, 1999). Metamorphic conditions are between amphibolite and greenschist facies (Fuck et al., 1981; Moraes and Fuck, 1994, 1999), though at the base of the Juscelândia sequence, granulite facies conditions have been described locally in pillowed metabasalt (Ferreira Filho et al., 1999) to the west of Barro Alto township. Amphibolite to greenschist facies conditions dominate the Indaianópolis and Palmeirópolis sequences (Brod and Jost, 1991, 1994; Araújo et al., 1995). Geochemical characteristics of mafic and felsic rocks suggest a transitional setting between a continental rift and an ocean basin as the most likely tectonic setting of volcanism and sedimentation of the Juscelândia sequence (Moraes et al., 2003).

\section{Available isotopic data for the layered mafic-ultramafic bodies and volcanosedimentary sequences}

The first geochronological data for Barro Alto, Niquelândia, and Cana Brava rocks were $\mathrm{K}-\mathrm{Ar}$ ages obtained in the early 1970s. Results vary between 550 and $4125 \mathrm{Ma}$ (Hasui and Almeida, 1970; Souza, 1973; Cordani and Hasui,
1975; Matsui et al., 1976), with the oldest values being interpreted as the result of excess radiogenic ${ }^{40} \mathrm{Ar}$ in the analyzed samples and the youngest values as cooling ages related to the Brasiliano Orogeny (Cordani and Hasui, 1975; Matsui et al., 1976). Since then, a significant amount of $\mathrm{U}-\mathrm{Pb}$ geochronological work and some $\mathrm{Rb}-\mathrm{Sr}, \mathrm{Sm}-\mathrm{Nd}$, and $\mathrm{Re}-\mathrm{Os}$ isotopic studies have been carried out on these rocks. The age of metamorphism seems well constrained in the mafic-ultramafic layered bodies. The age of igneous crystallization of the layered complexes was only recently determined, but we offer the first precise data for the volcanic sequences. We present a comprehensive summary of all geochronological data in Table 1 .

\subsection{The lower layered series}

In the Barro Alto Complex, zircon crystals from quartz metadiorite analyzed by ID-TIMS yield a highly discordant upper intercept date of approximately $1.73 \mathrm{Ga}$ (Suita et al., 1994). In the Niquelândia Complex, zircon from comparable intrusive quartz diorite into the lower layered series is highly discordant and suggests dates of 1.56-1.60 Ga (IDTIMS, U-Pb data by Ferreira Filho et al., 1994). SIMS $\mathrm{U}-\mathrm{Pb}$ data (SHRIMP) for the Barro Alto and Niquelândia complexes yield concordant analyses of approximately 770 $780 \mathrm{Ma}$, as well as strongly discordant analytical points between 0.77 and $2.0 \mathrm{Ga}$ (Correia et al., 1996). Analyses of a zircon grain from a Niquelândia metagabbro produce a single concordant point that has been used to suggest an age of approximately $2.0 \mathrm{Ga}$ for magmatic crystallization (Correia et al., 1996).

In the Cana Brava Complex, a whole-rock Sm-Nd isochron yields a date of around $1.97 \mathrm{Ga}$, interpreted as the time of igneous crystallization (Fuji, 1989). In recent studies, the intrusive quartz diorite from the Niquelândia Complex, studied by Ferreira Filho et al. (1994), has been suggested to be a late rock evolved from the magma that generated the lower layered series; U-Pb SIMS (SHRIMP) and Sm-Nd data indicate a different history for the igneous evolution of the Niquelândia Complex. Zircon grains of a quartz metadiorite have typical magmatic oscillatory zoning and two rims, generally a bright luminescent zone with high $\mathrm{Th} / \mathrm{U}$ ratios, and yield a concordant date of $797 \pm 10 \mathrm{Ma}$. Within uncertainty, these dates are similar to $\mathrm{Sm}-\mathrm{Nd}$ isochron age of $767 \pm 38 \mathrm{Ma}$ for a gabbronorite and therefore are interpreted as the age of crystallization of the lower layered series (Pimentel et al., 2004). Zircon from a websterite of the ultramafic zone, with preserved cumulus texture, has been dated at $799 \pm 6 \mathrm{Ma}$ (Pimentel et al., 2004).

\subsection{The upper layered series and granite intrusions}

The upper layered series rocks and granite bodies probably crystallized during the Mesoproterozoic. In the Barro Alto Complex, igneous zircon crystals from pegmatitic gabbro (equivalent to the Cafelândia amphibolite) and cordieritegarnet-sillimanite gneiss (metamorphosed peraluminous granite) 
Table 1

Summary of previous geochronological works for the mafic-ultramafic complexes and volcanosedimentary sequences

\begin{tabular}{|c|c|c|c|c|c|c|c|}
\hline Unit & Method & System & Rock & Mineral & Date (Ma) & Interpretation & Reference \\
\hline \multicolumn{8}{|l|}{ Lower layered series } \\
\hline \multirow[t]{2}{*}{ Barro Alto complex } & ID-TIMS & $\mathrm{U}-\mathrm{Pb}$ & Quartz diorite & Zircon & $1729 \pm 21$ & Crystallization age (upper intercept) & 5 \\
\hline & SIMS & $\mathrm{U}-\mathrm{Pb}$ & Diorite & Zircon & $796 \pm 20$ & Metamorphic age & 8 \\
\hline \multirow[t]{10}{*}{ Niquelândia complex } & ID-TIMS & $\mathrm{U}-\mathrm{Pb}$ & Quartz diorite & Zircon & $794 \pm 6$ & Metamorphic age (lower intercept) & 4 \\
\hline & ID-TIMS & $\mathrm{U}-\mathrm{Pb}$ & Quartz diorite & Zircon & $1565 \pm 22$ & Crystallization age (upper intercept) & \\
\hline & ID-TIMS & $\mathrm{U}-\mathrm{Pb}$ & Quartz diorite & Rutile & $659 \pm 2$ & Milder later metamorphic event & 4 \\
\hline & SIMS & $\mathrm{U}-\mathrm{Pb}$ & Gabbro & Zircon & $778 \pm 16$ & Metamorphic age (lower intercept) & 6 \\
\hline & SIMS & $\mathrm{U}-\mathrm{Pb}$ & Gabbro & Zircon & $1991 \pm 49$ & Crystallization age (upper intercept) & \\
\hline & N-TIMS & $\mathrm{Re}-\mathrm{Os}$ & $\begin{array}{l}\text { Several with igneous } \\
\text { texture }\end{array}$ & WR & $2070 \pm 70$ & Crystallization age & 6 \\
\hline & N-TIMS & $\mathrm{Re}-\mathrm{Os}$ & $\begin{array}{l}\text { Several with metamp. } \\
\text { texture }\end{array}$ & WR & $\sim 800$ & Metamorphic age & 6 \\
\hline & ID-TIMS & Sm-Nd isochron & Several rocks & WR & $776 \pm 25$ & Metamorphic age & 8 \\
\hline & SIMS & $\mathrm{U}-\mathrm{Pb}$ & Diorite & Zircon & $797 \pm 10$ & Crystallization age & 12 \\
\hline & ID-TIMS & Sm-Nd isochron & Gabbronorite & $\mathrm{WR}+\mathrm{Min}$ & $767 \pm 38$ & Crystallization age & 12 \\
\hline Cana Brava complex & ID-TIMS & $\mathrm{Sm}-\mathrm{Nd}$ isochron & Mafic rocks & WR & ca. $1.97 \mathrm{Ga}$ & Crystallization age & \\
\hline \multicolumn{8}{|c|}{ Upper layered series and granitic bodies } \\
\hline \multirow[t]{6}{*}{ Barro Alto complex } & ID-TIMS & $\mathrm{Rb}-\mathrm{Sr}$ isochron & Felsic granulite & WR & $1266 \pm 17$ & Metamorphic age & 2 \\
\hline & ID-TIMS & $\mathrm{U}-\mathrm{Pb}$ & Felsic granulite & Zircon & $1267 \pm 9$ & Crystallization age & 5 \\
\hline & SIMS & $\mathrm{U}-\mathrm{Pb}$ & Felsic granulite & Zircon & $1235 \pm 120$ & Metamorphic age & 8 \\
\hline & SIMS & $\mathrm{U}-\mathrm{Pb}$ & Felsic granulite & Zircon & $1286 \pm 13$ & Metamorphic age & 9 \\
\hline & SIMS & $\mathrm{U}-\mathrm{Pb}$ & Felsic granulite & Zircon & $1302 \pm 32$ & Metamorphic age & 9 \\
\hline & ID-TIMS & $\mathrm{U}-\mathrm{Pb}$ & Pegmatitic gabbro & Zircon & $1280 \pm 14$ & Crystallization age & 5 \\
\hline \multirow[t]{10}{*}{ Niquelândia complex } & ID-TIMS & $\mathrm{U}-\mathrm{Pb}$ & Anorthosite & Zircon & $777 \pm 11$ & Metamorphic age (lower intercept) & 4 \\
\hline & & & & & $1583 \pm 25$ & Crystallization age (upper intercept) & \\
\hline & ID-TIMS & $\mathrm{U}-\mathrm{Pb}$ & Anorthosite & Zircon & $784 \pm 5$ & Metamorphic age & 4 \\
\hline & ID-TIMS & $\mathrm{U}-\mathrm{Pb}$ & Anorthosite & Rutile & $689 \pm 34$ & Milder later metamorphic event & 4 \\
\hline & ID-TIMS & Sm-Nd isochron & Leucotroctolite & WR & $1347 \pm 69$ & Crystallization age & 10 \\
\hline & ID-TIMS & Sm-Nd isochron & Amphibolite & WR & $1352 \pm 99$ & Crystallization age & 10 \\
\hline & ID-TIMS & Sm-Nd isochron & Garnet rich amphibolite & WR & $610 \pm 32$ & Later metamorphic event & 10 \\
\hline & ID-TIMS & $\mathrm{U}-\mathrm{Pb}$ & Quartz rich mylonite & Zircon & $786 \pm 5$ & Metamorphic age & 4 \\
\hline & SIMS & $\mathrm{U}-\mathrm{Pb}$ & Quartz rich mylonite & Zircon & $765 \pm 8$ & Metamorphic age (lower intercept) & 12 \\
\hline & SIMS & $\mathrm{U}-\mathrm{Pb}$ & Quartz rich mylonite & Zircon & $1248 \pm 23$ & $\begin{array}{l}\text { Gabbro crystallization age (upper } \\
\text { intercept) }\end{array}$ & \\
\hline \multicolumn{8}{|c|}{ Volcano-sedimentary sequences } \\
\hline \multirow[t]{2}{*}{ Juscelândia sequence } & ID-TIMS & $\mathrm{Rb}-\mathrm{Sr}$ isochron & Biotite gneiss & WR & $1330 \pm 65$ & Metamorphic age & 2 \\
\hline & ID-TIMS & Sm-Nd errochron & Biotite gneiss & WR & $1280 \pm 150$ & Crystallization & 11 \\
\hline Indaianópolis sequence & SIMS & $\mathrm{U}-\mathrm{Pb}$ & Gneiss (meta-volcanic) & Zircon & $1299 \pm 39$ & Metamorphism & 9 \\
\hline \multirow[t]{2}{*}{ Palmeirópolis sequence } & ID-TIMS & $\mathrm{Rb}-\mathrm{Sr}$ isochron & & WR & $1157 \pm 50$ & Metamorphic age & 1 \\
\hline & ID-TIMS & $\mathrm{Pb}-\mathrm{Pb}$ & & Galena & $1.17-1.27 \mathrm{Ga}$ & Ore formation & 7 \\
\hline \multicolumn{8}{|c|}{ Basement granite and gneisses affected by Rio Maranhão thrust system } \\
\hline & ID-TIMS & $\mathrm{Rb}-\mathrm{Sr}$ & Mylonitic gneiss & WR & $644 \pm 27$ & Metamorphism & 1 \\
\hline & SIMS & $\mathrm{U}-\mathrm{Pb}$ & Granite & Zircon & $2128 \pm 15$ & Crystallization & 8 \\
\hline
\end{tabular}

1, Girardi et al. (1978); 2, Fuck et al. (1989); 3, Fuji (1989); 4, Ferreira Filho et al. (1994); 5, Suita et al. (1994); 6, Correia et al. (1996); 7, Araújo et al. (1996); 8, Correia et al. (1997a,b); 9, Correia et al. (1999); 10, Ferreira Filho and Pimentel (2000); 11, Moraes et al. (2003); 12, Pimentel et al. (2004). 
were analyzed by ID-TIMS (U-Pb) and yielded dates of approximately 1.28 and $1.27 \mathrm{Ga}$, respectively (Suita et al., 1994). A whole-rock $\mathrm{Rb}-\mathrm{Sr}$ isochron of similar felsic granulite yields a date of around $1.27 \mathrm{Ma}$, which has been interpreted as the time of high-grade metamorphism (Fuck et al., 1989). Following this early interpretation, SIMS zircon dates of 1.24 and $1.29 \mathrm{Ga}$ of deformed and metamorphosed intrusive granites were interpreted as the time of high-grade metamorphism (Correia et al., 1997a, 1999). $\varepsilon_{\mathrm{Nd}}$ for the Cafelândia amphibolite and a felsic granulite, calculated for $1.27 \mathrm{Ga}$, are, respectively, +4.2 and -4.45 . $T_{\mathrm{DM}}$ of the latter is $1.94 \mathrm{Ga}$, indicating that its protolith originated from the melting of older continental crust (Moraes et al., 2003).

In the Niquelândia Complex, two whole-rock $\mathrm{Sm}-\mathrm{Nd}$ isochrons of rocks of the upper layered series yield dates of approximately $1.35 \mathrm{Ga}$ with $\varepsilon_{\mathrm{Nd}}(T)$ in the range of $+4.8-4.1$ (Ferreira Filho and Pimentel, 2000). Zircon grains from a kyanite-garnet-quartz rich mylonite, hosted by a shear zone inside the upper layered series, yield a SIMS U-Pb date of $1248 \pm 23 \mathrm{Ma}$, considered the age of crystallization of the surrounding gabbros (Pimentel et al., 2004).

\subsection{Volcanosedimentary sequences}

The first geochronological data for the volcanosedimentary sequences were provided by whole-rock $\mathrm{Rb}-\mathrm{Sr}$ isochrons for the Palmeirópolis (Girardi et al., 1978) and Juscelândia (Fuck et al., 1989) sequences that yielded, respectively, dates of approximately 1.16 and $1.33 \mathrm{Ga}$, interpreted as the time of amphibolite facies metamorphism. $\mathrm{Pb}-\mathrm{Pb}$ dates in the range 1.17-1.27 Ga of galena from a synvolcanic base metal ore deposit hosted by mantle-derived rocks of the Palmeirópolis sequence have been interpreted as the approximate age of formation of the deposit (Araújo et al., 1996). The $\mathrm{Pb}-\mathrm{Pb}$ ages suggest that $\mathrm{Rb}-\mathrm{Sr}$ dates represent crystallization ages instead of the time of metamorphism.

In the Indaianópolis Sequence, zircon grains from a rock described as paragneiss yield a ${ }^{206} \mathrm{~Pb} /{ }^{238} \mathrm{U}$ SIMS date of approximately $1.3 \mathrm{Ga}$. Although this date was originally interpreted as the time of metamorphism (Correia et al., 1999), we suggest it is the age of volcanism, because the rock analyzed is not a paragneiss but a felsic metavolcanic rock with partially preserved igneous structures and textures. This interpretation is also supported by a poorly constrained whole-rock Sm-Nd isochron date of approximately $1.28 \mathrm{Ga}$ for Juscelândia metavolcanic rocks (Moraes et al., 2003). $\varepsilon_{\mathrm{Nd}}$ $(T=1.28 \mathrm{Ga})$ ranges between -2.8 and 4.5 in felsic volcanic rocks and between +2.8 and 5.5 in mafic volcanic rocks of Juscelândia (Moraes et al., 2003). $T_{\mathrm{DM}}$ values of these rocks are in the range 1.8-2.1 Ga, indicating that Paleoproterozoic crustal material was involved in the genesis of felsic magma (Moraes et al., 2003). In light of the geochronological data available, it seems likely that the volcanosedimentary sequences in the northern Goiás Massif formed during the Mesoproterozoic (Moraes et al., 2003) and thus are coeval with gabbro and anorthosite of the upper layered series (Ferreira Filho and Pimentel, 2000).

\subsection{Metamorphism}

The age of high-grade metamorphism in the three layered bodies is around 0.77 and $0.79 \mathrm{Ga}$, as indicated by SIMS and ID-TIMS U-Pb concordant zircon analyses (Ferreira Filho et al., 1994; Suita et al., 1994; Correia et al., 1996, 1997a,b, 1999). Recent SIMS dates obtained from zircon grains in kyanite-garnet-quartz-rich mylonite from the Niquelândia Complex yield $765 \pm 4 \mathrm{Ma}$, interpreted as the best estimate for the age of metamorphism (Pimentel et al., 2004). A Sm-Nd mineral isochron for a Cana Brava metagabbro yields a similar age of approximately $0.77 \mathrm{Ga}$, also interpreted as the age of high-grade metamorphism (Correia et al., 1997b). A younger metamorphic event is also recorded in some rocks of the Niquelândia Complex, in that rutile fractions from rocks of the lower and upper series are concordant and yield ${ }^{207} \mathrm{~Pb} /{ }^{206} \mathrm{~Pb}$ dates of approximately 0.66 and $0.69 \mathrm{Ga}$, respectively (Ferreira Filho et al., 1994). Similarly, a Sm-Nd mineral isochron (garnet-amphibolewhole-rock) of a garnet-rich band of the Niquelândia upper layered series yields approximately $0.61 \mathrm{Ga}$, interpreted as indicative of a typical Brasiliano metamorphic event (Ferreira Filho and Pimentel, 2000), as is recorded in several other rock units in the Brasília belt (Pimentel et al., 1991, 1997, 2000; Fischel et al., 1998; Piuzana et al., 2003a,b). The first reliable metamorphic ages for the volcanosedimentary sequences are presented here.

\subsection{Rio Maranhão thrust system}

Two age determinations are available for gneiss and granite deformed within the Rio Maranhão thrust system, exposed to the east of the mafic-ultramafic layered bodies. A whole-rock $\mathrm{Rb}-\mathrm{Sr}$ isochron including mylonite samples from a shear zone at the eastern border of the Cana Brava Complex yields a date of approximately $0.64 \mathrm{Ga}$, interpreted as metamorphic recrystallization during the Brasiliano Orogeny (Girardi et al., 1978). Zircon grains from orthogneiss at the eastern margin of the Barro Alto Complex have a SIMS U-Pb date of around $2.13 \mathrm{Ga}$ (Correia et al., 1997a), which indicates original igneous crystallization of the tonalite protolith.

\section{Description of selected samples}

Two samples of the Juscelândia Sequence (RM220, garnet amphibolite and RM75, kyanite-staurolite-garnetbiotite schist), one sample of the Cafelândia amphibolite (803-135), and one sample of Barro Alto felsic granulite (RM570) were selected for mineral separation and $\mathrm{Sm}-\mathrm{Nd}$ analysis. Zircon grains of two Juscelândia felsic rocks (RM29 and RM268) were separated for SIMS (SHRIMP) $\mathrm{U}-\mathrm{Pb}$ dating.

RM220 is a medium-grained garnet amphibolite with nematoblastic fabric that forms a LS tectonite; prismatic hornblende is overgrown by garnet and defines the pervasive lineation; its mineralogy also includes quartz, plagioclase $\left(\mathrm{An}_{95}\right)$, and ilmenite with zircon and apatite as accessory 
minerals. RM75 is a pelitic schist displaying complex reaction relationships between the metamorphic minerals and suggesting the following mineral succession: biotite, garnet, staurolite, kyanite, sillimanite, cordierite, and chlorite, which define a clockwise $P$ - $T$ path. Its metamorphic peak was reached at $610 \pm 12{ }^{\circ} \mathrm{C}$ at $5.6 \pm 0.6 \mathrm{kbar}$ (Moraes and Fuck, 1999). Foliation is defined by biotite, kyanite, and staurolite; plagioclase presents strong zoning with $\mathrm{An}_{89-75}$ in cores and $\mathrm{An}_{58-42}$ in rims. The higher anorthite contents in the cores are interpreted as preserved detrital grains from an igneous source (Moraes and Fuck, 1999).

RM29 is a medium- to fine-grained felsic metavolcanic rock of rhyolite composition that bears ellipsoidal quartz grains with preserved embayment (Moraes and Fuck, 1994); the foliation is due to aligned muscovite and minor biotite, as well as quartz and feldspar elongate grains. Intense deformation is recognized by the presence of mylonite in local shear zones. RM268 is very similar to this sample, though it is medium to coarse grained; the mylonite fabric is pervasive throughout the outcrop; biotite predominates over muscovite; and microcline is more abundant. The homogeneous fabric, mineralogy, and medium to coarse grain size indicate the protolith of this rock is subvolcanic or plutonic.

The Cafelândia amphibolite sample (803-135) is a coarse-grained banded rock of hornblende, clinopyroxene, garnet, quartz, and plagioclase; large orthopyroxene grains, up to $1 \mathrm{~cm}$ long, with recrystallized rims and many exsolution lamellae are common and interpreted as igneous relicts, whereas small, clean granoblastic grains are interpreted as metamorphic orthopyroxene; ilmenite, titanite, apatite, and zircon are accessory phases. Compositional banding is marked by modal variation mainly in the amounts of amphibole and garnet; leucosome is fairly common, with garnet, hornblende, and orthopyroxene as peritectic phases. Garnet, clinopyroxene, and quartz, which occur in mutual contact, and rare orthopyroxene define granulite facies conditions for this rock.

RM570 is a felsic granulite with xenoliths of mafic granulite. It is composed of quartz, perthitic K-feldspar, antiperthitic plagioclase, Ti-rich biotite, orthopyroxene, and garnet; rutile, ilmenite, apatite, and zircon occur in accessory amounts. Fine-grained orthopyroxene, garnet, quartz, and feldspar grains define a mylonitic foliation.

\section{Analytical procedures}

$\mathrm{Sm}-\mathrm{Nd}$ isotopic analyses were carried out at the Geochronology Laboratory of Universidade de Brasília. Sample dissolution was carried out in sealed Savillex capsules. Two initial digestions with $\mathrm{HF}-\mathrm{HNO}_{3}$ were followed by digestion with $\mathrm{HCl} 6 \mathrm{~N}$. Rare earth elements were separated in cation exchange columns, and $\mathrm{Sm}$ and $\mathrm{Nd}$ were separated by reverse chromatography using columns with HDEHP (di-2-ethyl-hexil phosphoric acid) supported by PTFE Teflon powder. Ln-Spec resin was also used. A mixed tracer solution of ${ }^{149} \mathrm{Sm}-{ }^{150} \mathrm{Nd}$ was used. Sm and Nd samples were deposited on double-Re filaments, and isotopic analyses were performed in static mode, using a Finnigan MAT 262 mass spectrometer. Uncertainties in $\mathrm{Sm} / \mathrm{Nd}$ and ${ }^{143} \mathrm{Nd} /{ }^{144} \mathrm{Nd}$ ratios are better than $\pm 0.3 \%(2 \sigma)$ and $\pm 0.005 \%(2 \sigma)$, respectively, according to repeated analyses of international rock standards BCR- 1 and BHVO- $1 .{ }^{143} \mathrm{Nd} /{ }^{144} \mathrm{Nd}$ ratios were normalized to 0.7219 for the ${ }^{146} \mathrm{Nd} /{ }^{144} \mathrm{Nd}$ ratio. Total laboratory blanks of $\mathrm{Nd}$ for all the procedures are lower than $100 \mathrm{pg}$ (Gioia and Pimentel, 2000).

Zircon concentrates were extracted from $10 \mathrm{~kg}$ rock samples using conventional gravimetric (DENSITEST ${ }^{\circledR}$ ) and magnetic (Franz isodynamic separator) techniques at the Geochronology Laboratory of Universidade de Brasília. Final purification was achieved by hand picking using a binocular microscope.

SIMS analyses were carried out using SHRIMP I at the Research School of Earth Sciences (RSES), Australian National University, Canberra, Australia. Zircon grains were mounted in epoxy resin and polished. Transmitted and reflected light microscopy, as well as scanning electron microscope cathodoluminescence imagery, was used to investigate the internal structures of the zircon crystals prior to analysis. Data were collected and reduced as recommended by Williams and Claesson (1987) and Compston et al. (1992). Uncertainties reported in Tables 2 and 3 are given at the $1 \sigma$ level, and the final ages are quoted at the $95 \%$ confidence level. Reduction of raw data was carried out using Squid 1.02 (Ludwig, 2001). U/Pb ratios were referenced to the RSES standard zircon FC1 (1099 Ma, $\left.{ }^{* 206} \mathrm{~Pb} /{ }^{238} \mathrm{U}=0.1859\right)$. $\mathrm{U}$ and $\mathrm{Th}$ concentrations were determined relative to those measured in the RSES standard SL13.

\section{Isotopic results}

\subsection{Zircon morphology and SHRIMP ages}

Zircon grains in sample RM29 are small $(<100 \mu \mathrm{m})$, prismatic, and pinkish. Cathodoluminescence images reveal that most crystals display thin oscillatory zoning, though some also present sector zoning. Isotopic results from both types of grains do not reveal age differences. Many crystals have a thin, bright luminescent rim, interpreted as metamorphic overgrowth. Only three were thick enough to be analyzed. Zircon grains in sample RM268 are much larger $(>200 \mu \mathrm{m})$, compatible with the interpretation that this rock represents a subvolcanic or plutonic body instead of a volcanic layer. They are prismatic, and their internal structures are characterized by both oscillatory and sector zoning, similar to sample RM29.

SIMS analyses of zircon grains from sample RM29 (Table 2) reveal a complex pattern with at least two possible events of strong $\mathrm{Pb}$ loss. However, the three bright luminescent rims investigated yield an average ${ }^{206} \mathrm{~Pb} /{ }^{238} \mathrm{U}$ age of $745 \pm$ $10 \mathrm{Ma}$ (95\% confidence, MSWD of 0.11 , Fig. 3a), which is interpreted as the best estimate for the age of metamorphic recrystallization. Seven analyses of cores forming a coherent concordant group yield an average ${ }^{207} \mathrm{~Pb} /{ }^{206} \mathrm{~Pb}$ date of $1277 \pm$ $15 \mathrm{Ma}$ (MSWD of 0.79 , Fig. 3a) that we interpret as the crystallization age of this volcanic rock. Zircon cores with 
Table 2

SIMS (SHRIMP) U-Pb data for sample RM29 of the Juscelândia sequence

\begin{tabular}{|c|c|c|c|c|c|c|c|c|c|c|c|c|c|c|c|c|c|}
\hline $\begin{array}{l}\text { Grain. } \\
\text { Spot }\end{array}$ & $\%{ }^{206} \mathrm{~Pb}_{\mathrm{c}}$ & ppm U & ppm Th & $\begin{array}{l}{ }^{232} \mathrm{Th} / \\
{ }^{238} \mathrm{U}\end{array}$ & $\underset{{ }^{206} \mathrm{~Pb}^{*}}{\mathrm{ppm}}$ & $\begin{array}{l}(1)^{206} \mathrm{~Pb} / \\
(\mathrm{Ma})\end{array}$ & ${ }^{38} \mathrm{U}$ Age & $\begin{array}{l}\text { (1) }{ }^{207} \mathrm{~Pb} \\
\text { Age }(\mathrm{Ma})\end{array}$ & & $\begin{array}{l}\% \text { Dis- } \\
\text { cordant }\end{array}$ & & $\pm \%$ & $\begin{array}{l}{ }^{(1)} \\
{ }^{207} \mathrm{~Pb}^{*} / \\
{ }^{235} \mathrm{U}\end{array}$ & $\pm \%$ & $\begin{array}{l}{ }^{(1)}{ }^{206} \mathrm{~Pb}^{*} / \\
{ }^{238} \mathrm{U}\end{array}$ & $\pm \%$ & err corr \\
\hline 1.1 & 0.31 & 242 & 134 & 0.57 & 51.1 & 1,415 & \pm 13 & 1,979 & \pm 19 & 29 & 0.1216 & 1.1 & 4.113 & 1.5 & 0.2454 & 1.0 & 0.701 \\
\hline 2.1 & 0.55 & 61 & 46 & 0.78 & 12.1 & 1,320 & \pm 18 & 1,237 & \pm 54 & -7 & 0.0817 & 2.7 & 2.558 & 3.1 & 0.2271 & 1.5 & 0.479 \\
\hline 3.1 & 0.10 & 136 & 60 & 0.46 & 42.4 & 2,001 & \pm 20 & 2,074 & \pm 19 & 4 & 0.1282 & 1.1 & 6.43 & 1.6 & 0.3639 & 1.2 & 0.738 \\
\hline 4.1 & 3.95 & 202 & 98 & 0.50 & 60.2 & 1,846 & \pm 22 & 2,005 & \pm 36 & 8 & 0.1236 & 2.0 & 5.64 & 2.4 & 0.3316 & 1.4 & 0.566 \\
\hline 5.1 & 0.30 & 180 & 141 & 0.81 & 35.3 & 1,324 & \pm 13 & 1,278 & \pm 26 & -4 & 0.0834 & 1.3 & 2.621 & 1.7 & 0.2280 & 1.1 & 0.639 \\
\hline 6.1 & 0.47 & 68 & 53 & 0.81 & 13.0 & 1,287 & \pm 17 & 1,267 & \pm 57 & -2 & 0.0829 & 2.9 & 2.525 & 3.3 & 0.2209 & 1.4 & 0.443 \\
\hline 7.1 & 0.12 & 264 & 249 & 0.97 & 49.8 & 1,277 & \pm 12 & 1,260 & \pm 22 & -1 & 0.08261 & 1.1 & 2.496 & 1.5 & 0.2191 & 1.0 & 0.676 \\
\hline 8.1 & 3.65 & 309 & 105 & 0.35 & 46.1 & 998 & \pm 10 & 1,042 & \pm 83 & 4 & 0.0740 & 4.1 & 1.709 & 4.3 & 0.1675 & 1.1 & 0.254 \\
\hline 9.1 & 0.56 & 200 & 159 & 0.82 & 37.2 & 1,260 & \pm 13 & 1,242 & \pm 30 & -1 & 0.0819 & 1.6 & 2.436 & 1.9 & 0.2158 & 1.1 & 0.580 \\
\hline 10.1 & 0.69 & 85 & 66 & 0.81 & 15.8 & 1,260 & \pm 16 & 1,207 & \pm 63 & -4 & 0.0804 & 3.2 & 2.392 & 3.5 & 0.2158 & 1.4 & 0.397 \\
\hline 11.1 & 0.60 & 249 & 137 & 0.57 & 39.5 & 1,086 & \pm 11 & 1,016 & \pm 35 & -7 & 0.0731 & 1.7 & 1.850 & 2.0 & 0.1836 & 1.1 & 0.528 \\
\hline $12.1 \mathrm{r}$ & 0.13 & 1169 & 6 & 0.01 & 124 & 747.7 & \pm 7.8 & 747 & \pm 15 & 0 & 0.06415 & 0.73 & 1.088 & 1.3 & 0.1230 & 1.1 & 0.833 \\
\hline 13.1 & 0.13 & 256 & 58 & 0.24 & 65.8 & 1,686 & \pm 17 & 1,935 & \pm 15 & 13 & 0.11858 & 0.84 & 4.886 & 1.4 & 0.2988 & 1.2 & 0.810 \\
\hline 12.2 & 2.30 & 124 & 66 & 0.55 & 16.7 & 923 & \pm 12 & 1,254 & \pm 120 & 26 & 0.0823 & 5.9 & 1.75 & 6.1 & 0.1539 & 1.4 & 0.223 \\
\hline 14.1 & 0.00 & 757 & 881 & 1.20 & 145 & 1,299 & \pm 11 & $1,286.7$ & \pm 9.6 & -1 & 0.08375 & 0.49 & 2.578 & 1.1 & 0.2232 & 0.93 & 0.883 \\
\hline 15.1 & 1.84 & 367 & 184 & 0.52 & 63.2 & 1,158 & \pm 11 & 1,287 & \pm 38 & 10 & 0.0838 & 1.9 & 2.272 & 2.2 & 0.1968 & 1.0 & 0.464 \\
\hline $15.2 \mathrm{r}$ & 1.67 & 405 & 32 & 0.08 & 43.2 & 742.6 & \pm 7.3 & 900 & \pm 62 & 17 & 0.0690 & 3.0 & 1.162 & 3.2 & 0.1221 & 1.0 & 0.324 \\
\hline $16.1 \mathrm{r}$ & 31.59 & 4 & 0 & 0.01 & 0.6 & 776 & 88 & - & - & - & - & - & - & - & 7.89 & 12.2 & - \\
\hline 17.1 & 1.35 & 43 & 22 & 0.51 & 8.27 & 1,273 & \pm 21 & 1,524 & \pm 74 & 16 & 0.0948 & 3.9 & 2.85 & 4.3 & 0.2183 & 1.8 & 0.412 \\
\hline 17.2 & 0.11 & 132 & 49 & 0.38 & 42.9 & 2,064 & \pm 21 & 2,187 & \pm 21 & 6 & 0.1368 & 1.2 & 7.12 & 1.7 & 0.3774 & 1.2 & 0.695 \\
\hline
\end{tabular}

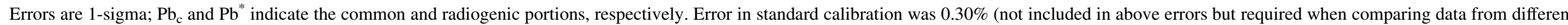
mounts). (1) Common $\mathrm{Pb}$ corrected using measured ${ }^{204} \mathrm{~Pb}$. $\mathrm{r}$ - metamorphic rim. 


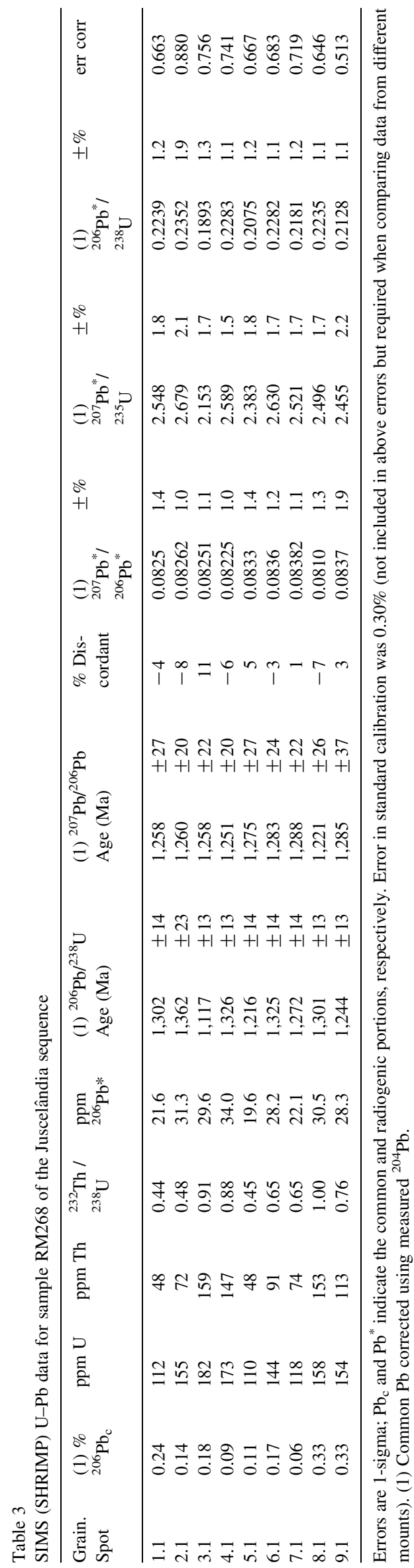

${ }^{206} \mathrm{~Pb} /{ }^{238} \mathrm{U}$ dates younger than around $1.2 \mathrm{Ga}$ may indicate strong $\mathrm{Pb}$ loss due to the amphibolite facies metamorphism; those older than $1.2 \mathrm{Ga}$ form a poorly defined discordia between approximately 1.3 and $2.0 \mathrm{Ga}$, representing inheritance (Fig. 3a). A mean ${ }^{207} \mathrm{~Pb} /{ }^{206} \mathrm{~Pb}$ for the five less discordant analyses of this group provide a date of $2022 \pm 130$, interpreted as a rough estimate of the age of the sialic source sampled by the Mesoproterozoic felsic magma.

SIMS U-Pb zircon analyses of sample RM268 define a simpler pattern with a straightforward interpretation (Table 3). The average of nine analytical points yields a date of $1263 \pm$ $15 \mathrm{Ma}$ (MSWD of 0.81 , Fig. 3b), which we interpret as the crystallization age of the subvolcanic/plutonic granite protolith.

\section{2. $S m-N d$ ages}

Although unsupported by field, petrographic, petrological, or mineral chemistry evidence, some authors favor multiple metamorphic episodes for the Barro Alto and Juscelândia volcanosedimentary rocks (e.g. Correia et al., 1996, 1997a,b, 1999). We use the Sm-Nd method to assess the age of metamorphism in garnet-bearing rocks in two samples of supracrustal rocks of the Juscelândia sequence. Analyses of garnet concentrate and whole-rock samples of garnet amphibolite RM220 yield a date of $754 \pm 33$ Ma (Fig. 4a, Table 4), and the mineral isochron (garnet-staurolite-wholerock) for kyanite-staurolite-garnet-biotite schist (RM75) indicates an age of $767 \pm 72 \mathrm{Ma}$ (Fig. 4b, Table 4). Analyses of whole-rock and concentrates of garnet and clinopyroxene from one sample of the Cafelândia amphibolite (803-135) yield a poorly constrained isochronic date of $766 \pm 150 \mathrm{Ma}$ (Fig. 4c, Table 4). Finally, a garnet-whole-rock isochron of Barro Alto felsic granulite RM570 yields a date of $745 \pm 26$ (Fig. 4d, Table 4). Therefore, despite the larger uncertainties given by the $\mathrm{Sm}-\mathrm{Nd}$ mineral isochrons, the dates are within error of the U-Pb date of $745 \pm 10 \mathrm{Ma}$ from three metamorphic zircon overgrowths in sample RM-29.

\section{Discussion}

SIMS U-Pb zircon ages of metavolcanic (RM29) and metagranite (RM268) rocks, as well as a $\mathrm{Sm}-\mathrm{Nd}$ isochron age published in a previous study (Moraes et al., 2003), indicate that Juscelândia bimodal volcanism and sedimentation occurred during the Mesoproterozoic, around 1.26-1.28 Ga. Sm-Nd mineral isochrons suggest that a Neoproterozoic metamorphic event affected both the Barro Alto Complex and Juscelândia sequence. Ages between approximately 745 and $767 \mathrm{Ma}$ recorded by the Sm-Nd mineral isochrons are similar, within error, to a SIMS U-Pb age for metamorphic zircon overgrowth recorded in the felsic metavolcanic sample RM29 (745 $\pm 10 \mathrm{Ma})$.

The data presented in this study clarify the role of the Juscelândia sequence in the regional geological evolution of the Brasilia belt. The age of the lower layered series of all three mafic-layered bodies seems Neoproterozoic, in 

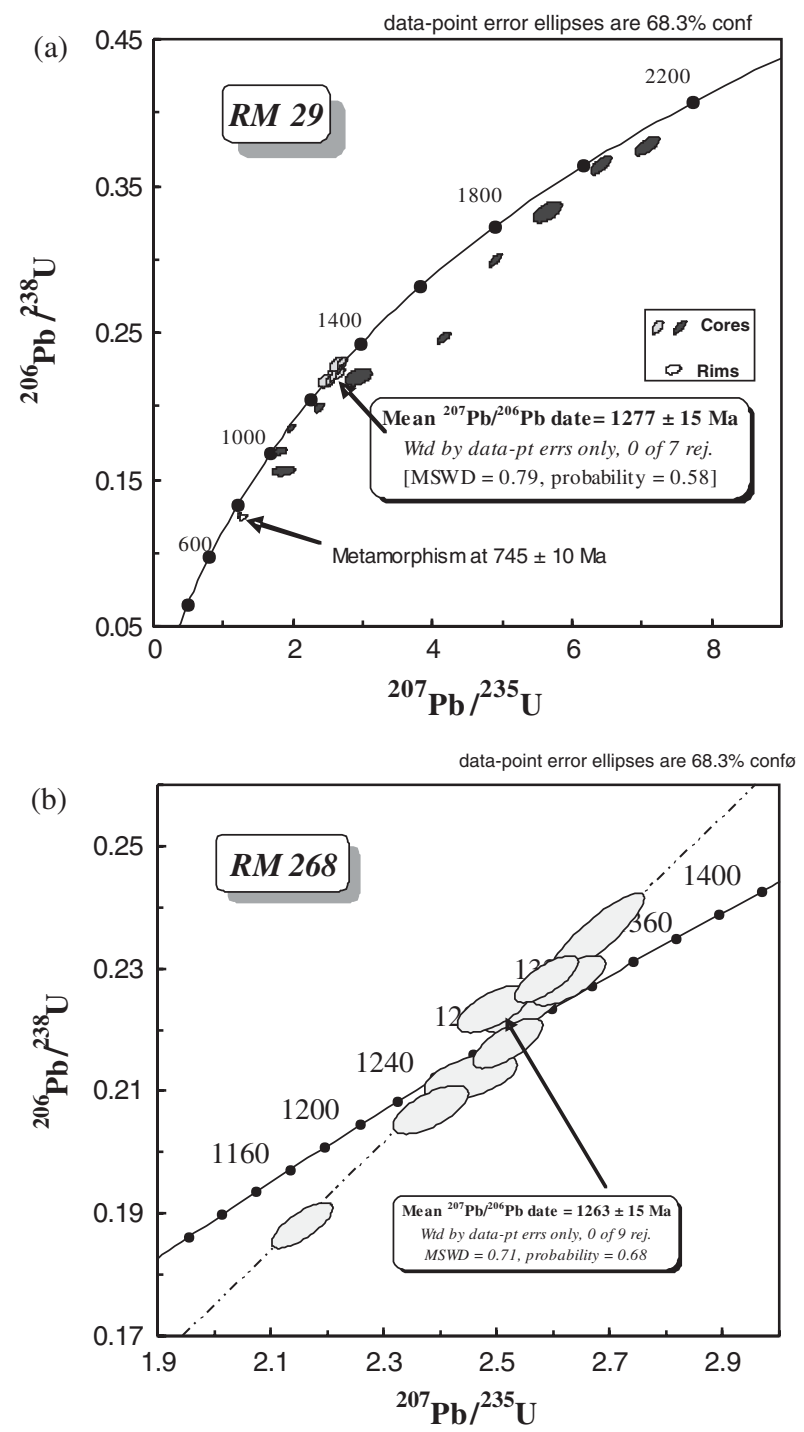

Fig. 3. (a) Concordia diagram of zircon SIMS analyses of sample RM29 of the Juscelândia sequence. RM29 is a metavolcanic rock. Mean ${ }^{207} \mathrm{~Pb} /{ }^{206} \mathrm{~Pb}$ age is $1277 \pm 15 \mathrm{Ma}(n=7)$. Older discordant values in the diagram are interpreted as cores of inherited grains. Age of metamorphism is dated to $745 \pm 10 \mathrm{Ma}$. (b) Concordia diagram of zircon SIMS analyses of sample RM268 of the Juscelândia sequence. RM268 is a metasubvolcanic or metaplutonic rock. The mean ${ }^{207} \mathrm{~Pb} /{ }^{206} \mathrm{~Pb}$ age is $1263 \pm 15 \mathrm{Ma}(n=9)$; no inherited cores were detected.

accordance with the latest U-Pb SIMS data (Pimentel et al., 2004). Crystallization of Juscelândia volcanic rocks was synchronous with crystallization of plutonic rocks of the upper layered series of the Barro Alto Complex (Cafelândia amphibolite) and equivalent rocks in the Niquelândia Complex, which crystallized between 1.28 and $1.35 \mathrm{Ga}$ (Suita et al., 1994; Ferreira Filho and Pimentel, 2000; Pimentel et al., 2004).

The Barro Alto felsic granulite represents a partially crustderived granite generated by the melting of older continental crust, as suggested by its peraluminous composition, presence of xenoliths of country rocks, negative $\varepsilon_{\mathrm{Nd}}$ value, and Paleoproterozoic Sm-Nd $T_{\mathrm{DM}}$ model age (Fuck et al., 1981; Moraes et al., 2003). These granitic ellipsoidal bodies occur inside the lower layered series, a Neoproterozoic unit (Pimentel et al., 2004), and have been dated at around 1.27 Ga (Fuck et al., 1989; Suita et al., 1994). In the past, these bodies in the Barro Alto Complex have been described as intrusions due to their shape in map (Fuck et al., 1989; Moraes and Fuck, 1994, 1999, 2000). However, because the lower layered series rocks were dated as Neoproterozoic (Pimentel et al., 2004), these granitic bodies intrusions must be younger, and available dates might be from inherited zircon grains. The whole-rock $\mathrm{Rb}-\mathrm{Sr}$ system preserves this inherited signature, even after ultra-hightemperature metamorphism (ca. $980{ }^{\circ} \mathrm{C}$ at $8 \mathrm{kbar}$ ), which converted the rocks into aluminous granulites with spinel, cordierite, sillimanite, Al-rich orthopyroxene, and garnet (Moraes and Fuck, 2000). The Mesoproterozoic Rb-Sr age is very similar to ID-TIMS and SIMS U-Pb data (Suita et al., 1994; Correia et al., 1997a, 1999). Some authors have interpreted the Mesoproterozoic $\mathrm{U}-\mathrm{Pb}$ dates as the time of the main metamorphism (Correia et al., 1997a, 1999), though there is neither petrographic nor field evidence of more than one pervasive metamorphic episode. The $1.26-1.35 \mathrm{Ga}$ time interval marks the opening of a continental rift, with the intrusion of mantle-derived magma (Cafelândia amphibolite and related rocks), partial melting of continental crust with subsequent inception, and opening of an ocean basin with oceanic crust formation, as is suggested by geochemical characteristics of the Juscelândia basic volcanic rocks (Moraes et al., 2003). This possibility has been also suggested previously for the plutonic association (Cafelândia amphibolite and $1.3 \mathrm{Ga}$ felsic granitic rocks) in the Barro Alto Complex (Suita, 1996).

These data indicate that high-grade metamorphism of the Barro Alto Complex and Juscelândia sequence took place at approximately $750 \mathrm{Ma}$. This metamorphic event includes the ultra-high-temperature metamorphism recorded by the Barro Alto aluminous granulites (Moraes and Fuck, 2000) and the transition of amphibolite to granulite facies in the Juscelândia rocks (Moraes and Fuck, 1994, 1999; Ferreira Filho et al., 1999). Because this metamorphic event is 150 $130 \mathrm{Ma}$ older than the main metamorphic event in the Brasília belt, which occurred around 650-630 Ma (Pimentel et al., 1991, 1997; Fischel et al., 1998; Piuzana et al., 2003a,b), it cannot be related to the main collision that formed the Brasilia belt. Perhaps an early collision between the Goiás Massif and the São Francisco plate, or between the Goiás magmatic arc and the Goiás Massif, triggered the older metamorphic event. Metamorphic recrystallization related to $650-630 \mathrm{Ma}$ metamorphism is not evident or pervasive within the layered granulite complexes or volcanosedimentary sequences. It seems to have affected some rocks locally in discrete shear zones as observed and dated in the Niquelândia Complex, where later metamorphism is recorded by a Sm-Nd garnet-whole-rock isochron of an upper layered series garnet-rich amphibolite layer (Ferreira Filho and Pimentel, 2000). The Rio Maranhão thrust system, along which granulites of the three layered complexes and associated rocks were exhumed, seems to have formed during the main metamorphic event affecting 

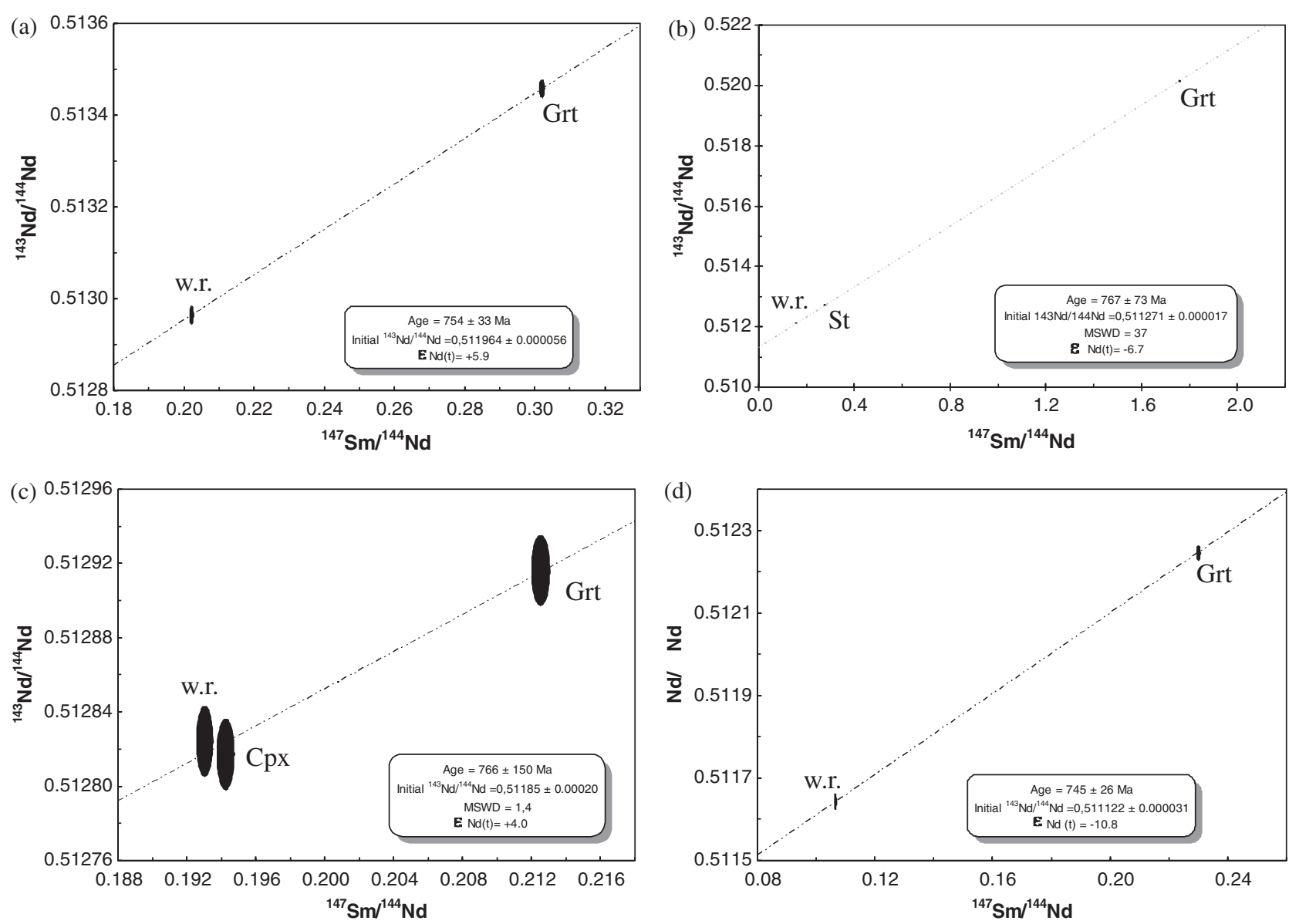

Fig. 4. (a) Sm-Nd isochron for sample RM220 of the Juscelândia sequence of whole-rock and garnet concentrate. (b) Sm-Nd isochron for sample RM75 of the Juscelândia sequence of whole-rock, staurolite, and garnet. (c) Sm-Nd isochron for sample 803-135 of the Cafelândia amphibolite of whole-rock, clinopyroxene, and garnet. (d) Sm-Nd isochron for sample RM570 of the Barro Alto Complex of whole-rock and garnet concentrate. Abbreviations: Grt, garnet; Cpx, clinopyroxene; St, staurolite; w.r., whole rock.

the Brasilia belt; the whole-rock $\mathrm{Rb}-\mathrm{Sr}$ isochron for mylonites east of the Cana Brava Complex provides an age of approximately $644 \mathrm{Ma}$ (Girardi et al., 1978).

Granulites of the Barro Alto, Niquelândia, and Cana Brava complexes tectonically overlie Paleoproterozoic granite and orthogneiss along the Rio Maranhão thrust system. Deformation and low-grade metamorphism are restricted to the fault zone and small-scale shear zones that cut granulites and volcanosedimentary rocks. Metamorphism caused by advective heat from granulites seems

Table 4

Sm-Nd data for rocks of the Barro Alto Complex and Juscelândia sequence

\begin{tabular}{|c|c|c|c|c|c|c|c|}
\hline Sample & Rock or mineral type & $\mathrm{Sm}(\mathrm{ppm})$ & $\mathrm{Nd}(\mathrm{ppm})$ & ${ }^{147} \mathrm{Sm} /{ }^{144} \mathrm{Nd}$ & ${ }^{144} \mathrm{Nd} /{ }^{143} \mathrm{Nd}$ & $\varepsilon_{\mathrm{Nd}}(1.27 \mathrm{Ga})$ & $T_{\mathrm{DM}}(\mathrm{Ga})$ \\
\hline RM268 & $\begin{array}{l}\text { Juscelândia sequence } \\
\text { meta subvolcanic }\end{array}$ & 7.641 & 35.160 & 0.1314 & 0.511921 & -3.73 & 2.00 \\
\hline RM75 & Pelitic schist & 7.061 & 30.311 & 0.1408 & 0.511982 & -3.51 & 2.12 \\
\hline RM75 & Garnet & 0.468 & 1.361 & 1.7595 & 0.520151 & & \\
\hline RM75 & Staurolite & 0.191 & 0.419 & 0.2763 & 0.512730 & & \\
\hline RM220 & Garnet amphibolite & 3.924 & 11.717 & 0.2024 & 0.512964 & +5.42 & 1.17 \\
\hline RM220 & Garnet & 1.464 & 2.931 & 0.3022 & 0.513457 & & \\
\hline $803-135$ & Cafelândia & 4.720 & 14.797 & 0.1931 & 0.512824 & +4.23 & 1.53 \\
\hline $803-135$ & Clinopyroxene & 1.086 & 3.378 & 0.1943 & 0.512817 & & \\
\hline $803-135$ & Garnet & 1.928 & 5.48 & 0.2126 & 0.512916 & & \\
\hline RM570 & Barro Alto & 4.051 & 22.940 & 0.1066 & 0.511642 & -4.45 & 1.94 \\
\hline RM570 & $\begin{array}{l}\text { Felsic granulite garnet } \\
\text { Standard }\end{array}$ & 13.600 & 35.727 & 0.2301 & 0.512245 & & \\
\hline La Jolla & & & & & 0.511853 & & \\
\hline $\mathrm{JM}$ & & & & & 0.512255 & & \\
\hline
\end{tabular}


Rift stage with basalt and Cafelândia amphibolite protolith formation

(a)

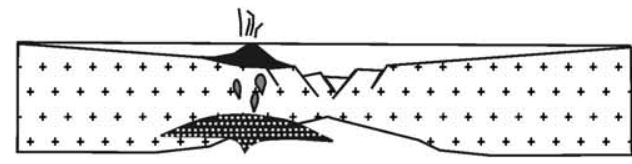

Rift to ocean basin transition - bimodal volcanism

(b)

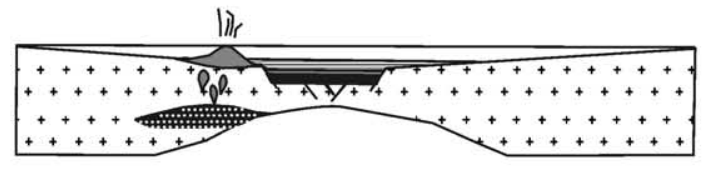

Ocean basin with N-MORB volcanism

(c)

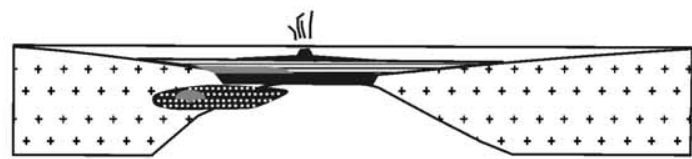

(d)

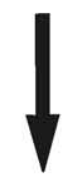

$?$

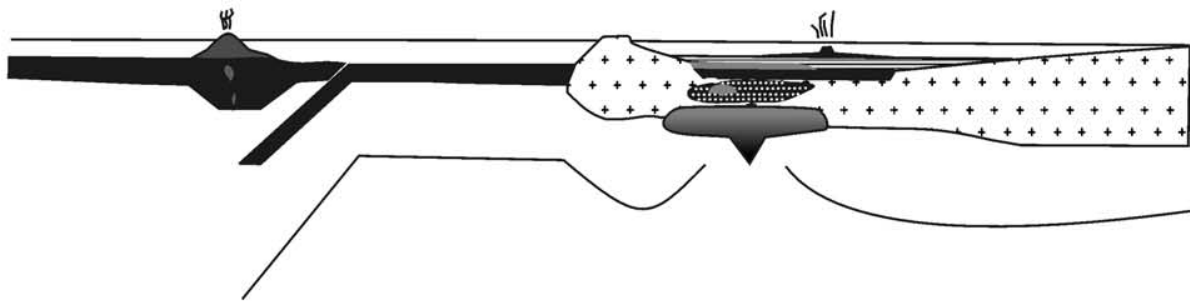

(e)

Barro Alto and Juscelândia metamorphism

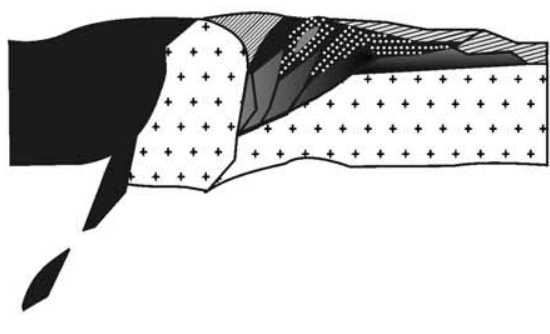

Fig. 5. (a) Mesoproterozoic stage (1.3-1.26 Ga) begins with continental rifting, intrusion of the upper layered series (Cafelândia amphibolite), and (b) extrusion of basalts of the Juscelândia sequence. (c) Also during the Mesoproterozoic stage, felsic magmatism documented by granitic intrusions and volcanic rocks of Juscelândia sequence; rifting evolved until ocean basin formation. (d) Neoproterozoic stage I (ca. $0.79 \mathrm{Ga}$ ), intrusion of the lower layered series of the Barro Alto Complex plus late tonalite to quartz diorite rocks. (e) Neoproterozoic stage II (ca. $0.75 \mathrm{Ga}$ ), metamorphism affecting layered mafic-ultramafic bodies and felsic rocks under ultra-high-temperature conditions $\left(T>950{ }^{\circ} \mathrm{C}\right)$ and volcanosedimentary sequences under granulite to amphibolite facies conditions. It is followed by a late Neoproterozoic stage $(0.65-0.63 \mathrm{Ga})$ that marks the apex of Brasiliano Orogeny, when slices of Brasília belt basement, such as the rocks of the Barro Alto Complex and Juscelândia sequence, were exhumed and incorporated to the Brasília orogen. 
negligible, in that only the growth of small garnet grains and plagioclase saussuritization is observed in the underlying rocks, which suggests granulites were already cold during their ascent and exhumation. Regional geophysical data indicate a strong gravimetric gradient along the contact zone between the granulites and underlying orthogneiss that has been interpreted as a suture between different crustal blocks (Marangoni et al., 1995). However, no geological features typical of suture zones, such as ophiolite or eclogite, are observed. We suggest that the Rio Maranhão thrust system is not a suture zone but rather a continental scale fault zone. This fault brought up a piece of the lower crust to shallow levels, apparently within the orogenic belt as a consequence of the final collision of the São Francisco and Amazon plates during the Neoproterozoic.

\section{Tectonic evolution}

We suggest the following tectonic evolution model for this part of the Brasília belt.

- Mesoproterozoic stage (1.3-1.26 Ga) Continental breakup begins with the intrusion of the upper layered series and extrusion of basalts of the Juscelândia sequence (Fig. 5a). Intrusion of hot mafic magma melts the continental crust, resulting in the generation of felsic magmatism, which formed intrusive plutonic granite bodies within the layered mafic rocks and extrusive felsic volcanic rocks of the Juscelândia sequence (Fig. 5b). Rifting progressed until the opening of an ocean basin and the formation of oceanic lithosphere (Fig. 5c).

- Neoproterozoic stage I (ca. $0.79 \mathrm{Ga}$ ) Intrusion of the lower layered series of the Barro Alto Complex (Fig. 5d).

- Neoproterozoic stage II (ca. $0.75 \mathrm{Ga}$ ) Metamorphism affected layered mafic-ultramafic bodies and felsic rocks under ultra-high-temperature conditions $\left(T>950{ }^{\circ} \mathrm{C}\right)$ and the volcanosedimentary sequences under amphibolite to granulite facies conditions. Metamorphism probably is related to the accretion of smaller blocks, such as the Goiás magmatic arc and Goiás Massif (Fig. 5e).

- Late Neoproterozoic (0.65-0.63 Ga) During the peak of Brasiliano Orogeny, slices of lower and middle crustal levels, such as rocks of the Barro Alto Complex and Juscelândia sequence, were exhumed along the Rio Maranhão thrust system and incorporated into the Brasília orogen.

\section{Conclusions}

New field and isotopic data provide some constraints on the origin and tectonic significance of the Juscelândia sequence. The new data, combined with previous studies (Moraes et al., 2003), demonstrate that the Juscelândia sequence, together with the plutonic Cafelândia amphibolite, is part of a Mesoproterozoic rift association that evolved from a continental rift to an oceanic basin around $1.27 \mathrm{Ga}$.
Its origin and tectonic formation setting are distinct from those of the adjacent Barro Alto lower series layered rocks, which means that these geological units were amalgamated later during the Neoproterozoic. This process is comparable to the Niquelândia Complex, where mafic-ultramafic granulites of the lower layered series are tectonically juxtaposed with the Mesoproterozoic upper layered series of oceanic affinity and the Indaianópolis sequence (Ferreira Filho and Pimentel, 2000; Pimentel et al., 2004). Although we present a tectonic model, it is still not completely clear in which kind of tectonic setting the intrusion and subsequent metamorphism of the Neoproterozoic lower layered series occurred, so that point should be investigated in more detail.

\section{Acknowledgements}

Constructive journal reviews by V. Pease and C.F. Ferreira Filho are appreciated. CNPq, Brazil (grant 46.0408/00-3 to RAF), is acknowledged for its support of field and laboratory work; RAF and MMP are CNPq research fellows.

\section{References}

Araújo, S.M., Nilson, A.A., 1988. Depósito de zinco, cobre e chumbo de Palmeirópolis, Goiás. In: Schobbenhaus, C., Coelho, C.E.S. (Eds.), Principais Depósitos Minerais do Brasil, 3. DNPM/CVRD, Brasília, pp. 171-180 (in Portuguese with abstract in English).

Araújo, S.M., Fawcett, J.J., Scott, S.D., 1995. Metamorphism of hydrothermally altered rocks in a volcanogenic massive sulfide deposit: the Palmeirópolis, Brazil, example. Revista Brasileira de Geociências 25, 173-184.

Araújo, S.M., Scott, S.D., Longstaffe, F.J., 1996. Oxygen isotope composition of alteration zones of highly metamorphosed volcanogenic massive sulfide deposits: Geco, Canada and Palmeirópolis, Brazil. Economic Geology 91, $697-712$.

Brod, J.A., Jost, H., 1991. Características estruturais, litológicas e magmáticas da zona de cisalhamento dúctil do Rio Traíras, bloco do Complexo Niquelândia, Goiás. Revista Brasileira de Geociências 21, 205-217 (in Portuguese with abstract in English)

Brod, J.A., Jost H., 1994 Revisão estratigráfica da região de Indaianópolis, In: $4^{\circ}$ Simpósio de Geologia do Centro-Oeste, SBG, Brasília, pp. 138-141 (in Portuguese).

Compston, W., Williams, I.S., Kirschvink, J.L., Zhang, Z., Guogan, M.A., 1992. Zircon U-Pb ages for the early Cambrian time-scale. Journal Geological Society London 149, 171-184.

Cordani, U.G., Hasui, Y., 1975. Comentários sobre os dados geocronológicos disponíveis para a folha Goiás. In: Schobbenhaus Filho, C. (Ed.), Carta Geológica do Brasil ao milionésimo, folha Goiás (SD 22). DNPM, Brasília, pp. 85-95, pp. 99-103 (in Portuguese).

Correia, C.T., 1994. Petrologia do Complexo Máfico-ultramáfico de Cana Brava, Goiás. Doctor Thesis, Instituto de Geociências, Universdade de São Paulo, 151 p. (in Portuguese with abstract in English).

Correia C.T., Girardi V.A.V., Lambert D.D., Kinny P.D., Reeves S.J., 1996. 2 $\mathrm{Ga}$ U-Pb (SHRIMP-II) and Re-Os ages for the Niquelândia basicultrabasic layered intrusion, central Goiás, Brazil. In: $39^{\circ}$ Congresso Brasileiro de Geologia. Abstract, vol. 1, SBG, Salvador, pp. 187-189.

Correia, C.T., Tassinari, C.C.G., Lambert, D.D., Kinny, P., Girardi, V.A.V., 1997a. U/Pb (SHRIMP), Sm-Nd and Re-Os systematic of the Cana Brava, Niquelândia and Barro Alto layered intrusions in the Central Brazil, and constraints on the tectonic evolution. In: South-American Symposium on Isotope Geology. Extended Abstract, Campos de Jordão, pp. 88-89. 
Correia, C.T., Girardi, V.A.V., Tassinari, C.C.G., Jost, H., 1997b. Rb-Sr and Sm-Nd geochronology of the Cana Brava layered mafic-ultramafic intrusion, Brazil, and considerations regarding its tectonic evolution. Revista Brasileira de Geociências 27, 163-168.

Correia, C.T., Jost, H., Tassinari, C.C.G., Girardi, V.A.V., Kinni, P.D., 1999. Ectasian Mesoproterozoic U-Pb ages (SHRIMP II) for the metavolcanosedimentary sequence of Juscelândia and Indaianópolis and for high grade metamorphosed rocks of Barro Alto stratiform igneous Complex, Goiás State, central Brazil. In: Second South American Symposium on Isotope Geology. Abstract, Cordoba, pp. 31-33.

Danni, J.C.M., Leonardos, O.H., 1980. Granulite metamorphism and deformation in ancient composite layered intrusions: the Niquelândia Complex, Brazil. In: Twenty-sixth International Geological Congress. Abstract, Paris. vol. 1, pp. 35-37.

Danni, J.C.M., Fuck, R.A., Kuyumjian, R.M., Leonardos, O.H., Winge, M., 1984. O Complexo de Barro Alto na região de Ceres-Rubiataba, Goiás. Revista Brasileira de Geociências 14, 128-136 (in Portuguese with abstract in English).

Ferreira C.F., 1998. Geology and petrology of the large layered intrusions of central Brazil: implications for PGE mineralization. In: Platinum Symposium. Rustemburg, South Africa. Extended Abstracts, pp. 107-110.

Ferreira Filho, C.F., Pimentel, M.M., 2000. Sm-Nd systematic and REE data for leucotroctolites and their amphibolitized equivalents of the Niquelândia complex upper layered series, central Brazil: further constraints for the timing of magmatism and high grade metamorphism. Journal of South American Earth Sciences 13, 647-659.

Ferreira Filho, C.F., Kamo, S.L., Fuck, R.A., Krogh, T.E., Naldrett, A.J., 1994. Zircon and rutile $\mathrm{U}-\mathrm{Pb}$ geochronology of the Niquelândia layered mafic and ultramafic intrusion, Brazil: constraints for the timing of magmatism and the high grade metamorphism. Precambrian Research 68, 241-255.

Ferreira Filho, C.F., Naldrett, A.J., Gorton, M.P., 1995. Distribution of platinum group elements in the Niquelândia layered mafic-ultramafic intrusion, Brazil. Canadian Mineralogist 33, 165-184.

Ferreira Filho, C.F., Moraes, R., Fawcett, J.J., Naldrett, A.J., 1998a. Amphibolite to granulite progressive metamorphism in the Niquelândia complex, central Brazil: regional tectonic implication. Journal of South American Earth Sciences 11, 35-50.

Ferreira Filho, C.F., Naldrett, A.J., Gorton, M.P., 1998b. REE and pyroxene compositional variation across the Niquelândia mafic and ultramafic layered intrusion, Brazil: petrological and metallogenic implications. Transaction of the Institution of Mining and Metallurgy 107, 1-22.

Ferreira Filho, C.F., Araújo, S.M., Cruz, H.P., 1999. Estruturas vulcânicas preservadas em granulitos da sequência vulcano-sedimentar Juscelândia, GO. Revista Brasileira de Geociências 29, 461-469 (in Portuguese with abstract in English).

Fischel, D.P., Pimentel, M.M., Fuck, R.A., 1998. Idade do metamorfismo de alto grau no Complexo Anápolis-Itauçu, Goiás, determinada pelo método Sm-Nd. Revista Brasileira de Geociências 28, 543-544 (in Portuguese with abstract in English).

Fonseca, M.A., 1996. Estilos estruturais e arcabouço tectônico do segmento setentrional da Faixa Brasília. Doctor Thesis. Instituto de Gecociências, Univesidade de Brasília, $172 \mathrm{p}$ (in Portuguese with abstract in English).

Fonseca M.M., Dardenne M.A., 1955 Tectônica transpressional no contexto do núcleo metamórfico externo da Faixa Brasília, em seu segmento setentrrional. In: $5^{\circ}$ Simpósio de Geologia do Centro-Oeste, Goiânia-GO, SBG, Brasília, pp. 84-86. (in Portuguese)

Fuck R.A., Danni J.C.M., Winge M., Andrade G.F., Barreira C.F., Leonardos O.H., Kuyumjian R.M., Geologia da Região de Goianésia. In: $1^{\circ}$ Simpósio de Geologia do Centro-Oeste, Goiânia, SBG, Núcleo Centro Oeste e Brasília, pp. 447-467 (in Portuguese with abstract in English).

Fuck R.A., Brito Neves B.B., Cordani U.G., Kawashita K., 1989. Geocronologia Rb-Sr no Complexo Barro Alto, Goiás: Evidência de metamorfismo de alto grau e colisão continental há 1300 Ma no Brasil Central. Geochimica Brasiliensis, vol. 3. pp. 125-140 (in Portuguese with abstract in English).
Fuck R.A., Pimentel M.M., Silva L.J.H.D., 1994. Compartimentação tectônica da porção oriental da Província Tocantins. In: $38^{\circ}$ Congresso Brasileiro de Geologia. Abstract in Portuguese, vol. 1. SBG, Balneário Camboriú, pp. 215-216 (in Portuguese).

Fuji, M.Y., 1989. REE geochemistry and Sm/Nd geochronology of the Cana Brava Complex, Brazil. Master Thesis, Kone University, Japan, 55p.

Gioia, S.M.C.L., Pimentel, M.M., 2000. Sm-Nd isotopic method in the geochronology laboratory of university of Brasília. Anais da Academia Brasileira de Ciências 72, 219-245.

Girardi V.A.V., Kawashita K., Basei M.A.S., Cordani U.G., 1978. Algumas considerações sobre a evolução geológica daa região de Cana Brava, a partir de dados geocronológicos. In: $30^{\circ}$ Congresso Brasileiro de Geologia, vol. 1. SBG, Recife, pp. 337-348. (in Portuguese).

Girardi, V.A.V., Rivalenti, G., Siena, F., Sinigoi, S., 1981. Precambrian barro alto complex of Goiás, Brazil: bulk geochemistry and phase equilibria. Neues Jahrbuch Fur Mineralogie-Abhandlungen 142, 270-291.

Girardi, V.A., Rivalenti, G., Sinigoi, S., 1986. The petrogenesis of the Niquelândia layered basic-ultrabasic Complex, central Goiás, Brazil. Journal of Petrology 27, 715-744.

Hasui, Y., Almeida, F.F.M., 1970. Geocronologia do Centro Oeste brasileiro. Boletim da Sociedade Brasileira de Geologia 19, 1-26 (in Portuguese).

Junges, S.L., Pimentel, M.M., Moraes, R., 2002. Nd Isotopic study of the Neoproterozoic Mara Rosa Arc, central Brazil: implications for the evolution of the Brasília Belt. Precambrian Research 117, 101-118.

Lima, T.M., 1997. Geologia, estratigrafia e petrologia da porção sul do Complexo máfico-ultramáfico de Cana Brava, Goiás. Master Dissertation. Instituto de Geociências, Universidade de Brasília, 312 p (in Portuguese with abstract in English).

Ludwig K.R., Squid 1.02. A User's Manual. BGC, Special Publication 2, Berkeley, 19p.

Marangoni, Y., Assumpção, M., Fernandes, E.P., 1995. Gravimetria em Goiás, Brasil. Revista Brasileira de Geofísica 13, 205-219 (in Portuguese with abstract in English).

Matsui K., Girardi V.A.V., Basei M.A.S., Hasui Y., 1976. Idades K/Ar do Complexo básico-ultrabásico Cana Brava-GO. $29^{\circ}$ Congresso Brasileiro de Geologia, vol. 4. SBG, Ouro Preto, pp. 269-277 (in Portuguese)

Moraes, R., Fuck, R.A., 1994. Deformação e metamorfismo das seqüências Juscelândia e Serra da Malacacheta, Complexo Barro Alto, Goiás. Revista Brasileira de Geociências 24, 189-197 (in Portuguese with abstract in English).

Moraes, R., Fuck, R.A., 1999. Trajetória $P-T$ horária para o metamorfismo da sequiência Juscelândia, Goiás: condições do metamorfismo e implicações tectônicas. Revista Brasileira de Geociências 29, 585-594 (in Portuguese with abstract in English).

Moraes, R., Fuck, R.A., 2000. Ultrahigh temperature metamorphism in central Brazil: the Barro Alto Complex. Journal of Metamorphic Geology 18, 345 358.

Moraes, R., Fuck, R.A., Pimentel, M.M., Gioia, S.M.C.L., Figueiredo, A.M.G., 2003. Geochemistry and $\mathrm{Sm}-\mathrm{Nd}$ isotopic characteristics of bimodal volcanic rocks of Juscelândia, Goiás, Brazil: Mesoproterozoic transition from continental rift to ocean basin. Precambrian Research 125, 317-336.

Pimentel, M.M., Heaman, L., Fuck, R.A., 1991. Zircon and sphene U-Pb geochronology of upper Proterozoic volcanic-arc rock units from southwestern Goiás, central Brazil. Journal of South American Earth Sciences 4, 295-305.

Pimentel, M.M., Whitehouse, M.J., Viana, M.G., Fuck, R.A., Machado, N., 1997. The Mara Rosa arc in the Tocantins province: further evidence for Neoproterozoic crustal accretion in central Brazil. Precambrian Research 81, 299-310.

Pimentel, M.M., Fuck, R.A., Jost, H., Ferreira Filho, C.F., Araújo, S.M., 2000. The Basement of the Brasília Fold Belt and the Goiás Magmatic Arc. In: Cordani, U.G., Milani, E.J., Thomaz Filho, A., Campos, D.A. (Eds.), Tectonic Evolution of South America. 31st International Geological Congress, Rio de Janeiro, pp. 195-229.

Pimentel, M.M., Ferreira Filho, C.F., Armstrong, R.A., 2004. SHRIMP U-Pb and Sm-Nd ages of the Niquelândia layered complex: Meso- $(1.25 \mathrm{Ga})$ and Neoproterozoic ( $0.79 \mathrm{Ga}$ ) extensional events in central Brazil. Precambrian Research 132, 133-153. 
Piuzana, D., Pimentel, M.M., Fuck, R.A., Armstrong, R., 2003a. Neoproterozoic granulite facies metamorphism and coeval granitic magmatism in the Brasília belt, central Brazil: regional implications of SHRIMP U-Pb and Sm-Nd data. Precambrian Research 125, 245-273.

Piuzana, D., Pimentel, M.M., Fuck, R.A., Armstrong, R., 2003b. SHRIMP U$\mathrm{Pb}$ and $\mathrm{Sm}-\mathrm{Nd}$ data for the Araxá group and associated magmatic rocks: constraints for the age of sedimentation and geodynamic context of the southern Brasília belt, central Brazil. Precambrian Research 125, 139-160

Ribeiro Filho, W., Teixeira, N.A., 1980. Sequência vulcano-sedimentares da borda oeste dos complexos de Niquelândia e Cana Brava. Goiânia. Boletim do Núcleo Centro-Oeste 10, 157-177 (in Portuguese).

Rivalenti, G., Girardi, V.A.V., Sinigoi, S., Rossi, A., Siena, F., 1982. The Niquelândia mafic-ultramafic complex of central Goiás, Brazil: petrological considerations. Revista Brasileira Geociências 12, 380-391 (in Portuguese with abstract in English).

Rudnick, R.L., 1990. Continental crust: growing from below. Nature 347, 711-712.

Sandiford, M., Powell, R., 1986. Deep crustal metamorphism during continental extension: modern and ancient examples. Earth Planetary Science Letters 79, 151-158.
Souza, A., 1973. Geologia e geocronologia do Complexo de Barro Alto, GO. Doctor Thesis, Faculdade de Filosofia Ciências e Letras de Rio Claro, 175 p (in Portuguese with abstract in English).

Suita, M.T.F., 1996. Geoquímica e metalogenia de elementos do grupo da Platina (EGP + Au) em complexos máfico-ultramáficos do Brasil: critérios e guias com ênfase no Complexo máfico-ultráfico acamadado de alto grau de Barro Alto (CBA, Goiás). Doctor Thesis. Instituto de Geociências, Universidade Federal do Rio Grande do Sul, 600 p (in Portuguese with abstract in English).

Suita, M.T.F., Kamo, S.L., Krough, T.E., Fyfe, W.S., Hartmann, L.A., 1994. U-Pb ages from the high grade Barro Alto mafic-ultramafic Complex (Goiás, central Brazil): Middle Proterozoic continental mafic magmatism and the Upper Proterozoic continental collision. In: Eighth International conference on geochronology, cosmochronology and isotope geology, Berkeley, 1994. US Geological Survey Circular 1107. Berkeley, pp. 309.

Williams, I.S., Claesson, S., 1987. Isotopic evidence for the provenance and Caledonian metamorphism of high grade paragneisses from the Seve Nappes, Scandinavian Caledonides: ion microprobe zircon U-Th-Pb. Contributions Mineralogy Petrology 97, 205-217. 